\title{
Job and personal resources as mediators in the relationship between iron-ore mineworkers' job demands and work engagement
}

\begin{tabular}{|c|c|}
\hline \multicolumn{2}{|c|}{$\begin{array}{l}\text { Authors: } \\
\text { Martina Kotzé1 } \\
\text { Petrus Nel }\end{array}$} \\
\hline \multicolumn{2}{|c|}{$\begin{array}{l}\text { Affiliations: } \\
{ }^{1} \text { Business School, University } \\
\text { of the Free State, } \\
\text { Bloemfontein, South Africa }\end{array}$} \\
\hline \multicolumn{2}{|c|}{$\begin{array}{l}{ }^{2} \text { Department of Industrial } \\
\text { Psychology, University } \\
\text { of the Free State, } \\
\text { Bloemfontein, South Africa }\end{array}$} \\
\hline \multicolumn{2}{|c|}{$\begin{array}{l}\text { Corresponding author: } \\
\text { Martina Kotzé, } \\
\text { kotzem@ufs.ac.za }\end{array}$} \\
\hline \multicolumn{2}{|c|}{$\begin{array}{l}\text { Received: } 04 \text { Mar. } 2019 \\
\text { Accepted: } 24 \text { May } 2019 \\
\text { Published: } 27 \text { Aug. } 2019\end{array}$} \\
\hline \multicolumn{2}{|c|}{$\begin{array}{l}\text { How to cite this article: } \\
\text { Kotzé, M., \& Nel, P. (2019). } \\
\text { Job and personal resources } \\
\text { as mediators in the } \\
\text { relationship between iron-ore } \\
\text { mineworkers' job demands } \\
\text { and work engagement. SA } \\
\text { Journal of Human Resource } \\
\text { Management/SA Tydskrif vir } \\
\text { Menslikehulpbronbestuur, } \\
\text { 17(0), a1183. https://doi.org/ } \\
10.4102 / \text { sajhrm.v17i0.1183 }\end{array}$} \\
\hline \multicolumn{2}{|c|}{$\begin{array}{l}\text { Copyright: } \\
\text { (C) 2019. The Authors. } \\
\text { Licensee: AOSIS. This } \\
\text { is licensed under the } \\
\text { Creative Commons } \\
\text { Attribution License. }\end{array}$} \\
\hline \multicolumn{2}{|l|}{ Read online: } \\
\hline 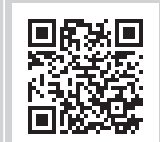 & $\begin{array}{l}\text { Scan this QR } \\
\text { code with your } \\
\text { smart phone or } \\
\text { mobile device } \\
\text { to read online. }\end{array}$ \\
\hline
\end{tabular}

Orientation: Mining companies are major sources of employment in South Africa. Withstanding the challenges that the mining industry faces, maintaining work engagement of employees is essential to success in this context.

Research purpose: To investigate the mediating effect of job and personal resources (in parallel and serial) in the relationship between the job demands and work engagement of employees at two iron-ore mines in a remote South African locale.

Motivation for the study: Most South African research on work engagement in the mining industry focuses on the role of job resources. There is a lack of research investigating the influence of both job and personal resources in the relationship between job demands and mineworkers' work engagement.

Research approach/design and method: Data were collected using questionnaires from 238 employees working for two open-pit iron-ore mines. Three mediating relationships were investigated using variance-based structural equation modelling.

Main findings: The results indicate that job and personal resources (in parallel) partially mediated the relationship between job demands and work engagement, with personal resources having a stronger effect than job resources. In addition, job and personal resources (in serial) partially mediated the relationship between job demands and work engagement but not as strongly as personal resources (in parallel).

Practical/managerial implications: Despite job demands, mineworkers' work engagement can be increased by investing in interventions and a work environment that enhances job and personal resources (such as mindfulness and psychological capital).

Contribution/value add: The study bridges a specific gap in the literature by exploring the role of both job and personal resources (i.e., mindfulness and psychological capital) in the relationship between mineworkers' job demands and work engagement. No previous studies explored these variables in combination in the South African mining industry.

Keywords: mindfulness; psychological capital; mineworkers; work engagement; job and personal resources in the mining industry.

\section{Introduction}

South African mines are significant sources of employment for local communities (Marais et al., 2018). Notwithstanding major changes in labour laws that improved working conditions of mineworkers over the past two decades, the mining industry is still marked by several job demands, such as work pressure, labour unrest, safety hazards, retrenchments, production demands, shift work and job insecurity (Abrahamsson et al., 2014; Malherbe \& Segal, 2000; Marais \& Cloete, 2013). To reduce operational costs and increase profits, mines locally and abroad, are seeking to produce more with fewer employees (Chen, Chen, Zhu, Qi, \& Long, 2015; Phakathi, 2011). Management encourages mineworkers to meet demanding production targets in exchange for bonuses. To secure these bonuses, workers often deviate from work rules and take risks and shortcuts - sometimes with serious implications for their safety and health (Chimamise et al., 2013). However, accidents and injuries in the mining environment are not only the result of job and production demands. Personal factors such as mineworkers' psychological well-being, negative affectivity and job dissatisfaction also lead to unnecessary risky behaviour that influences mineworkers' safety and accident proneness (Paul \& Maiti, 2007). 
To get the best out of mineworkers, managers need to keep mineworkers energised, focused and engaged. As engaged employees are more proactive in shaping their work environment and creating their own resources, they are more likely to handle job demands effectively (Bakker, Demerouti, \& Xanthopoulou, 2012). Past studies show that work engagement has the potential to create flourishing workplaces (Schaufeli \& Salanova, 2007), and that engaged employees outperform disengaged employees (Herbert, 2011; Youssef \& Luthans, 2007).

The Job Demands-Resources model (JD-R) (Bakker \& Demerouti, 2008) can assist managers in this regard as it shows how stressful job demands can be mitigated by job and personal resources to increase work engagement. Job demands are organisational, social or physical job aspects associated with psychological and physiological costs (Xanthopoulou, Bakker, Demerouti, \& Schaufeli, 2007) and may include excessive workload, intrusion of work into employees' private lives and time pressure. Job resources, such as managerial support, help employees reach their work goals and reduce job demands, while also assisting employees to develop personally. Personal resources refer to employees' ability to influence or control their work environment successfully. This includes qualities such as self-efficacy that fosters employee resilience (Bakker, 2009; Xanthopoulou et al., 2007). Bakker (2009) argues that both job and personal resources (separate or in combination) influence work engagement.

Past studies conducted in the South African mining industry show how job resources influence employees' work engagement. These studies found that perceived organisational support, such as work autonomy, communication, role clarity and supervisory and co-worker support (Mphahlele, Els, De Beer, \& Mostert, 2018; Palo \& Rothmann, 2016; Rothmann \& Joubert, 2007) enhance work engagement. On the other hand, few studies investigate the influence of personal resources on mineworkers' work engagement. De Beer, Tims and Bakker's (2016) study of several organisations in the South African mining and manufacturing industries shows that employees' proactive behaviour in the form of job crafting increased work engagement. Other recent South African studies outside the mining industry found that personal resources, such as psychological capital (PsyCap) and mindfulness, positively influence work engagement (Kotzé, 2018a, b). While PsyCap enhances proactive behaviour (Avey, Wernsing, \& Luthans, 2008; Bakker, Tims, \& Derks, 2012; Sameer, 2018), mindfulness encourages states of wakefulness and involvement, and, as a result, employees perform their work in more interesting and creative ways (Depenbrock, 2014; Langer \& Modoveanu, 2000; Leroy, Anseel, Dimitrova, \& Sels, 2013; Malinowski \& Lim, 2015).

No South African studies, to our knowledge, explore the influence of both job and personal resources on work engagement, specifically within the mining industry. To bridge this gap in the literature, this research explores the role of job and personal resources (i.e., mindfulness and PsyCap) in the relationship between mineworkers' job demands and work engagement.

\section{Job demands and work engagement}

Job demands are psychological, physical, social or organisational job-related aspects that require either psychological or physiological effort, associated with specific psychological or physical costs (Demerouti, Bakker, Nachreiner, \& Schaufeli, 2001; Schaufeli \& Bakker, 2004). Based on the challenge stressor-hindrance stressor framework (Cavanaugh, Boswell, Roehling, \& Boudreau, 2000), researchers distinguish two types of job demands: those incorporating 'challenges' (such as time pressure) and 'hindrances' (such as role conflict) to the achievement of work outcomes.

Most definitions of work engagement (see, e.g., Fernandez, 2007; Markos \& Sridevi, 2010; Schaufeli, 2013) include common elements such as employees' passionate drive towards, enthusiasm for, involvement in and commitment to their job or organisation. Schaufeli (2013, p. 25) describes work engagement as 'a positive, fulfilling, work-related state of mind that is characterised by vigour, dedication and absorption.' 'Vigour' means enhanced levels of mental resilience and energy and includes employees' preparedness to put effort into their work. It is seen as a motivational concept and is most apparent when employees approach their tasks with persistence and effort, despite difficulties at work. Employees with 'dedication' feel challenged, proud, inspired and enthusiastic, and experience a sense of significance about their work (Schaufeli, Salanova, GonzalezRoma, \& Bakker, 2002; Sonnentag, 2017). 'Absorption' involves immersion in one's work (Schaufeli, Martinez, Pinto, Salanova, \& Bakker, 2002). However, dedication and vigour are regarded as the 'core components' of work engagement (Schaufeli, 2013; Taris, Ybema, \& Van Beek, 2017).

Theoretically, the JD-R model does not assume there is a direct relation between job demands and work engagement (Bakker, Hakanen, Demrouti, \& Xanthopoulou, 2007), yet there is empirical evidence indicating that certain job demands are positively associated with work engagement (Mauno, Kinnunen, \& Ruokolaine, 2007). Although both types of job demands (challenges and hindrances) are positively related to job strain (Breevaart \& Bakker, 2018), some studies show that challenges, such as time pressure, contribute to employee motivation and are positively related to increased work engagement. Hindrances, such as role conflict and unreasonable intrusion of work into employees' private lives, on the other hand, are detrimental to employee motivation and show a negative association with work engagement (Breevaart \& Bakker, 2018; Inoue et al., 2014; Kotzé \& Nel, 2018; Van Der Broeck, De Cuyper, De Witte, \& Vansteenkiste, 2010). Therefore, the following hypothesis is proposed:

H1: Job demands (i.e., intrusion of work into private life) have a negative influence on mineworkers' work engagement. 


\section{Job resources: Mediating the job demands-work engagement relationship}

\section{The relationship between job demands and job resources}

Job resources refer to:

$[P]$ hysical, psychological, social, or organizational aspects of the job that either/or (1) reduce job demands and the associated physiological and psychological cost; (2) are functional in achieving work goals; (3) stimulate personal growth, learning and development. (Schaufeli \& Bakker, 2004, p. 296)

Job resources can be formal or informal. Organisations can provide formal support (through organisational practices or policies) or informal support (through supervisor or social support) (Hammer, Kossek, Yragui, Bodner, \& Hanson, 2009; Rhoades \& Eisenberger, 2002).

In the relationship between job demands and job resources, employees experiencing hindering job demands typically perceive their job resources as inefficient. Because perceptions influence peoples' cognitive appraisals of situations, employees' perceptions of organisations' formal and informal support override objective indicators of support (Glazer, 2006). When employees perceive job resources as insufficient, or are unable to mobilise it, it may overwhelm or discourage them (Duong, Tuckey, Hayward, \& Boyd, 2015). Hindering job demands cause stress, which may impede employees' ability to mobilise job resources (Bakker, Demerouti, \& Verbeke, 2004; Muse \& Pichler, 2011) and may undermine employees' perceptions of employers' care and respect for them (Liao, 2011).

\section{The relationship between job resources and work engagement}

Past studies show that job resources have a positive influence on work engagement (Mauno et al., 2007; Schaufeli, Bakker \& Van Rhenen, 2009). Liao (2011) uses Emerson's (1976) theory to explain that the organisation/ supervisor-employee relationship is characterised by a social exchange process. When employees experience their organisations as supportive (i.e., sufficient job resources), they will reciprocate this support by exhibiting a positive affect towards their work/organisation (e.g., work engagement) (Zhai, Wang, \& Weadon, 2017). Because high job demands, coupled with job resources, may lead to work engagement (Schaufeli \& Bakker, 2004), job resources are potential mechanisms influencing the negative relationship between job demands and work engagement. Resources can counteract hindering job demands and thereby protect employees (Breevaart \& Bakker, 2018; Ten Brummelhuis \& Bakker, 2012).

\section{The following hypothesis is therefore proposed:}

$\mathrm{H} 2$ : Job resources mediate the relationship between job demands and work engagement such that the indirect effect is negative.

\section{Personal resources (PsyCap and mindfulness): Mediating the job demands-work engagement relationship}

PsyCap is a second-order construct consisting of four integrated first-order constructs: self-efficacy, hope, optimism and resilience (Luthans, Youssef, \& Avolio, 2007). High self-efficacy occurs when employees have confidence in their capabilities to confront and accomplish challenging assignments (Luthans, Youssef-Morgan, \& Avolio, 2015). Hope enables individuals to stay focused on set goals, while creating alternative paths, when needed, to succeed. Optimism includes the belief that employees' efforts will result in positive outcomes presently and in future. Resilience is one's ability to cope despite problems, and to bounce back after setbacks (Snyder et al., 1991). As PsyCap creates positive emotions, it allows employees to evaluate interpersonal relations, job resources and other available support in a more positive light (Avey et al., 2008; Herbert, 2011). It is a statelike resource and can be developed, even through short training interventions (Luthans \& Youssef-Morgan, 2017).

Mindfulness is a conscious, non-judgmental awareness of, and attention to, every moment. It helps people focus on the present and stay conscious of any relevant internal and external stimuli, without being concerned with the past or future (Dane, 2011; Depenbrock, 2014). In the workplace, mindfulness assists employees to give attention to relevant occurrences and activities, acknowledge their own behaviour and feelings and manage negative feelings that may encourage harmful actions (Dane \& Brummel, 2013). Although mindfulness is an innate human ability that differs between individuals, employees can enhance mindfulness through various types of interventions (Brown \& Ryan, 2003; Leroy et al., 2013; Petchsawang \& McLean, 2017).

\section{The relationship between job demands and personal resources}

Persistent job demands may diminish and deplete employees' energetic resources as they draw on resources beyond employees' normal abilities (Grover, Teo, Pick, Roche, \& Newton, 2018). According to Bakker et al. (2004), job demands operate through a process of impairment, negatively influencing psychological and physical wellbeing. Job demands can drain employees' energy, and they may struggle to cope with the resulting exhaustion (Maslach, 1993). The impairment of employees' personal resources can result in job strain and, subsequently, a decreased willingness to invest themselves in their work (Breevaart \& Bakker, 2018). This indicates that there is a negative relationship between job demands and personal resources.

\section{The relationship between personal resources and work engagement}

Empirical studies in different types of work environments support the positive influence of PsyCap on work engagement (Constantini et al., 2017; Herbert, 2011; Roux, 2010; Simons \& Buitendach, 2013; Wang, Liu, Zou, Junhui, \& Wu, 2017). 
Some studies indicate that PsyCap, as a second-order construct, is a stronger predictor of work engagement than the four first-order constructs separately (Simons \& Buitendach, 2013). Other studies indicate that self-efficacy and optimism are the two strongest predictors of work engagement (Herbert, 2011; Roux, 2010). Wang et al. (2017) found that the second-order construct PsyCap, as well as two first-order constructs, hope and optimism, are significant predictors of work engagement.

Researchers found that mindfulness increases employees' work engagement because it stimulates personal flourishing (a state of optimal mental health; feeling good about yourself and your potential to contribute positively to the world around you) (Zheng, Gunasekara, \& Blaich, 2018). It also helps employees perform their work more creatively (Langer \& Modoveanu, 2000) and assists them to utilise the resources they need in order to be actively involved at work (Depenbrock, 2014). Based on this, the following hypothesis is proposed:

H3: Personal resources (i.e. PsyCap and mindfulness) mediate the relationship between job demands and work engagement such that the indirect effect is negative.

\section{Job resources and personal resources as mediators in serial}

Job resources stimulate the energy of employees and subsequently enable them to persist and persevere. Empirical evidence from a study by Xanthopoulou et al. (2007) helps explain the underlying psychological mechanisms of the motivational process of the JD-R model. The authors conclude that the availability of job resources activates employees' personal resources, making them 'feel more capable of controlling their work environment' (p. 136). Subsequently, being more proud and confident, and finding more meaning in their work, they stay engaged in their work. Past studies found that personal resources either mediate or partially mediate the relationship between job resources and work engagement, suggesting that job resources foster the development of personal resources (Demerouti \& Bakker, 2011; Xanthopoulou et al., 2007). Therefore, the following hypothesis is proposed:

$\mathrm{H} 4$ : Job resources and personal resources mediate in serial the relationship between job demands and work engagement such that the indirect effect is negative.

To explore the influence of job and personal resources in the relationship between job demands and work engagement, a conceptual model (Figure 1) was developed.

\section{Research design \\ Research approach}

This study was part of a larger interdisciplinary research project in which a cross-sectional design with a survey datacollection technique was used.

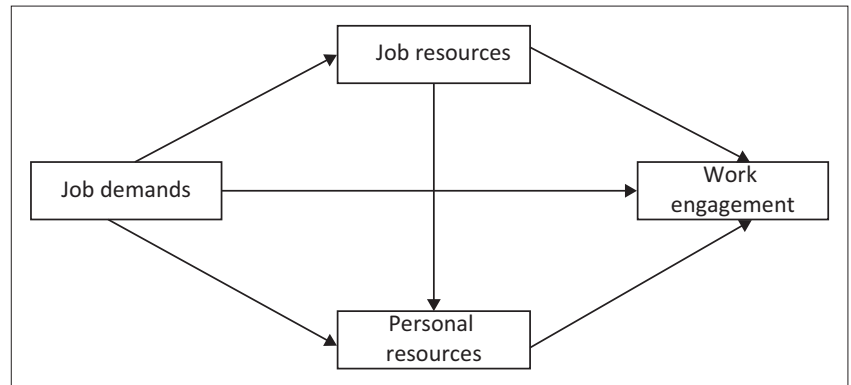

FIGURE 1: Conceptual model: The influence of job demands on work engagement mediated by job resources (employer respect and employee care) and personal resources (PsyCap and mindfulness).

\section{Research method}

\section{Participants}

Employees $(n=238)$ from two open-pit iron-ore mines (51\% and $49 \%$ split) in the Northern Cape in South Africa participated. The majority $(83 \%)$ are male, and over half (55\%) operate heavy-duty machinery and equipment. The rest are artisans, engineers, equipment or quality controllers, health and safety officers, or maintenance planners. Only $6 \%$ are supervisors or team leaders. Participants' average age was $36(S D=8.65)$. The majority $(62 \%)$ speak an indigenous African language, about 33\% are Afrikaans-speaking and 5\% indicated they speak other languages.

\section{Measuring instruments}

Job demands: 'Intrusion of work into private life' (six items) was used as the indicator for job demands. Items focus on whether employees feel stressed and pressured to meet targets, find it difficult to relax after work, and if work affects their private life or impacts negatively on their self-esteem (Parker \& Hyett, 2011).

Work engagement: The Utrecht Work Engagement Scale (UWES-9) was used to measure vigour and dedication (core constructs of work engagement) as a one-factor structure (De Bruin \& Henn, 2013; Schaufeli, Bakker, \& Salanova, 2006; Schaufeli, Salanova et al., 2002).

Personal resources: PsyCap and mindfulness were used as indicators of personal resources. The 15-item Mindful Attention Awareness Scale (MAAS) (Brown \& Ryan, 2003) was employed to measure mindfulness. The PsyCap Questionnaire (PCQ-24) containing the four subscales of PsyCap (self-efficacy, hope, optimism and resilience) (Luthans, Avolio, Avey, \& Norman, 2007; Grobler \& Joubert, 2018) measured PsyCap.

Job resources: Two scales from the Work Well-Being Questionnaire (Parker \& Hyett, 2011) were used as indicators of job resources. Organisational respect for employees (seven items) focused on whether employees view senior people in their organisation as trustworthy and whether the organisation values its staff and treats them well. Employee care (seven items) reflects the degree to which employees perceive their supervisors as caring, 
willing to listen, understanding of their work concerns, and treating employees as they wish to be treated.

\section{Statistical analysis}

The reliability of the measuring instruments was determined using Cronbach's alpha. Estimates as low as 0.6 may be acceptable when conducting exploratory research (Field, 2005; Hair, Black, Babin, Anderson, \& Tatham, 2006, pp. 137, 778). Pearson's Product Moment Correlation was used to determine the degree to which the independent variables are significantly correlated with work engagement. Variance-based structural equation modelling was employed to evaluate the different hypotheses. A two-step process should be followed when evaluating the results associated with variance-based structural equation modelling (Henseler, Ringle, \& Sinkovics, 2009). The outer model (i.e., measurement model) provides information as to the quality of the indicators used to operationalise each of the latent variables. The quality of the outer model is determined in terms of reliability and validity. Composite reliability estimates of 0.7 and higher, together with values of 0.5 and higher for the average variance extracted (AVE), are both evidence of an acceptable outer model. The indicators used to operationalise each latent variable must have statically significant loadings. The inner model (i.e., structural model) provides information on the strength (beta) and statistical significance ( $p$-values) of the associated paths in a theoretical model. Furthermore, the $R$-square value is an indicator of the proposed theoretical model's predictive power (Henseler et al., 2009). SmartPLS version 3 (Ringle, Wende, \& Becker, 2015) was used to evaluate all four of the hypotheses.

\section{Ethical considerations}

Ethical clearance number: UFS-HSD2015/0495. This project was part of a larger interdisciplinary project conducted at the mines in Postmasburg. The project leader was Prof. Philippe Burger.

\section{Results}

The results section includes several tables showing the statistical outcomes from the collected data. The reliability estimates for each variable are reported here (Table 1). It is evident from the data that all variables have acceptable levels of reliability, ranging between 0.6 (intrusion of work into private life) and 0.92 (mindfulness).

The results from correlating the variables show that they are all significantly associated with work engagement (Table 2).

\section{TABLE 1: Reliability estimates.}

\begin{tabular}{lcc}
\hline Variable & Cronbach's alpha & Number of items \\
\hline IWPL & 0.60 & 6 \\
ORE & 0.86 & 7 \\
ECARE & 0.89 & 7 \\
PsyCap & 0.82 & 24 \\
MIND & 0.92 & 15 \\
WE & 0.88 & 6 \\
\hline
\end{tabular}

IWPL, intrusion of work into private life; ORE, organisational respect; ECARE, employee care PsyCap, psychological capital; MIND, mindfulness; WE, work engagement.
Mindfulness $(r=0.429)$ and intrusion of work into private life $(r=-0.462)$ have the strongest relationship with work engagement. PsyCap $(r=0.295)$ has the weakest relationship with work engagement.

All the indicators used to operationalise each of the latent variables met the required quality criteria (Tables 3 and 4). All the indicators had acceptable composite reliabilities and values higher than 0.5 in terms of AVE.

The present study continued evaluating the inner model, emphasising both the size and significance of the proposed paths. All proposed paths are statistically significant (Table 5). This proposed model explained $33 \%$ of the variance in mineworkers' work engagement. Of importance is the direct path between job demands and work engagement. It is evident that job demands have a negative influence on work engagement $(-0.304)$. As this path is statistically significant $(p=0.000)$, the study finds support for Hypothesis 1.

TABLE 2: Correlations.

\begin{tabular}{lcccccc}
\hline Variable & $\mathbf{1}$ & $\mathbf{2}$ & $\mathbf{3}$ & $\mathbf{4}$ & $\mathbf{5}$ & $\mathbf{6}$ \\
\hline IWPL & 1.000 & - & - & - & - & - \\
ORE & -0.249 & 1.000 & - & - & - & - \\
ECARE & -0.278 & 0.864 & 1.000 & - & - & - \\
PsyCap & -0.235 & 0.291 & 0.276 & 1.000 & - & - \\
MIND & -0.373 & 0.204 & 0.224 & 0.281 & 1.000 & - \\
WE & -0.462 & 0.340 & 0.310 & 0.295 & 0.429 & 1.000 \\
\hline
\end{tabular}

IWPL, intrusion of work into private life; ORE, organisational respect; ECARE, employee care PsyCap, psychological capital; MIND, mindfulness; WE, work engagement.

TABLE 3: Outer model (quality criteria).

\begin{tabular}{lcc}
\hline Variable & Composite reliability & AVE \\
\hline$J D$ & 1 & 1 \\
$J R$ & 0.965 & 0.932 \\
PR & 0.777 & 0.637 \\
WE & 1 & 1 \\
\hline
\end{tabular}

AVE, average variance extracted; JD, job demands; JR, job resources; PR, personal resources; $W E$, work engagement.

TABLE 4: Outer loadings.

\begin{tabular}{lcccc}
\hline Path & Original sample (O) & STDEV & T statistics $(|\mathrm{O} / \mathrm{STDEV}|)$ & $\boldsymbol{p}$-values \\
\hline IWPL <-JD & 1.000 & 0.000 & - & - \\
ECARE $<-J R$ & 0.965 & 0.006 & 165.586 & 0.000 \\
ORE $<-J R$ & 0.965 & 0.006 & 165.301 & 0.000 \\
MIND <-PR & 0.858 & 0.040 & 21.212 & 0.000 \\
PsyCap <- PR & 0.733 & 0.067 & 10.902 & 0.000 \\
WE <-WE & 1.000 & 0.000 & - & -
\end{tabular}

STDEV, standard deviation; IWPL, intrusion of work into private life; ORE, organisational respect; ECARE, employee care; PsyCap, psychological capital; MIND, mindfulness; WE, work engagement.

TABLE 5: Path coefficients.

\begin{tabular}{lcccc}
\hline Path & Original sample (O) & STDEV & T statistics (|O/STDEV|) & $\boldsymbol{p}$-values \\
\hline JD - > JR & -0.273 & 0.069 & 3.935 & 0.0000 \\
JD $->$ PR & -0.328 & 0.056 & 5.888 & 0.0000 \\
JD - > WE & -0.304 & 0.066 & 4.627 & 0.0000 \\
JR $->$ PR & 0.225 & 0.077 & 2.900 & 0.0040 \\
JR $->$ WE & 0.162 & 0.068 & 2.365 & 0.0180 \\
PR $->$ WE & 0.293 & 0.079 & 3.698 & 0.0000 \\
\hline
\end{tabular}

STDEV, standard deviation; WE, work engagement; JD, job demands; JR, job resources; PR, personal resources. 
TABLE 6: Specific indirect effects.

\begin{tabular}{lcccc}
\hline Path & $\begin{array}{c}\text { Original } \\
\text { sample (0) }\end{array}$ & STDEV & $\begin{array}{c}\boldsymbol{T} \text { statistics } \\
\text { (O/STDEV) }\end{array}$ & $\boldsymbol{p}$-values \\
\hline $\mathrm{JD}->\mathrm{JR}->\mathrm{PR}$ & -0.061 & 0.027 & 2.31 & 0.021 \\
$\mathrm{JD}->\mathrm{JR}->$ WE & -0.044 & 0.022 & 1.967 & 0.050 \\
$\mathrm{JD}->\mathrm{PR}->$ WE & -0.096 & 0.033 & 2.909 & 0.004 \\
$\mathrm{JR}->\mathrm{PR}->$ WE & 0.066 & 0.029 & 2.257 & 0.024 \\
$\mathrm{JD}->\mathrm{JR}->\mathrm{PR}->$ WE & -0.018 & 0.009 & 2.087 & 0.037 \\
\hline
\end{tabular}

$\mathrm{O}$, original sample;STDEV, standard deviation; WE, work engagement; JD, job demands, JR, job resources; PR, personal resources.

The specific indirect effects (Table 6) are used to evaluate the proposed mechanisms through which the negative effect of job demands on work engagement is mediated.

Firstly, it is clear that the mechanism through which job demands affect work engagement (via job resources) is negative $(-0.044)$ and statistically significant $(p=0.050)$. Secondly, the mechanism through which job demands affect work engagement (via personal resources) is negative $(-0.096)$ and statistically significant $(p=0.004)$.

Interestingly, the effects of the mechanism through which job demands negatively influence work engagement (via personal resources) are stronger than via job resources. In short, these results indicate that job resources and personal resources only partially mediate (in parallel) the negative effect of job demands on work engagement. Therefore, both Hypothesis 2 and Hypothesis 3 are partially accepted.

The mechanism through which job demands negatively influence work engagement (via job resources, then personal resources) (-0.018) is also statistically significant $(p=0.037)$. These results show that job resources and personal resources only partially mediate (in serial) the negative effect of job demands on work engagement. As a result, Hypothesis 4 is partially accepted.

\section{Discussion}

The present study set out to determine the direct effect of job demands on work engagement, as well as the mediating effects of job and personal resources (in parallel) on the above relationship. Finally, the mediating effect of both job and personal resources (in serial/combination) was investigated.

Support was found for the negative effect of job demands on work engagement among the sample of mining employees. Bakker et al. (2004) propose that job demands negatively influence work engagement through an impairment process. It is assumed that when employees are faced with high job demands, their mental resources (and probably other resources) are diminished, leading to lower levels of work engagement. Continued exposure to high job demands also negatively influences health and well-being by requiring individuals to use more resources than they actually have (Schaufeli \& Taris, 2014).

The present study found that the two types of resources (job and personal in parallel) partially mediate the negative effect of job demands on work engagement. This is in line with the findings of Slöetjes (2012) on the mediating role of personal resources. According to Kanfer, Frese and Johnson (2017), motivation is usually a function of explicit personal factors (e.g. personality traits) and job-related contextual characteristics. As such, both job and personal resources influence the motivational levels of employees to be engaged with their work. Brouze (2013) reported that PsyCap partially mediates the motivational process of the JD-R Model, while Bakker and Demermouti (2016) state that individuals with access to job resources are more motivated to use these resources to successfully fulfil their job responsibilities and achieve their goals (Bakker \& Demerouti, 2016).

Interestingly, the mediating effect of personal resources on the relationship between job demands and work engagement is slightly stronger than the mediating effect of job resources. Schaufeli and Taris (2014) argue that it is possible that not all the resources in the JD-R model are equal. Therefore, in any given context, employees can place different motivational values on different resources. Whereas job resources function as external/contextual motivators (Schaufeli \& Taris, 2014), it is likely that personal resources (such as PsyCap and mindfulness) function as internal motivators. In addition, it is likely that because employees may have more control over their personal resources than their job resources, that the influence of personal resources may have a stronger mediating effect. Although, job demands had a negative effect on work engagement in the present study, this relationship was suppressed by the presence of both job and personal resources.

Finally, the present study found that the two types of resources (job and personal in serial) partially mediated the negative effect of job demands on work engagement - but not as strongly as found by the partial mediation in parallel. Previous research suggested that when individuals are faced with job demands, the availability of job resources activates their personal resources (Xanthopoulou et al., 2008). This seems plausible given that individuals use different resources in combination ('resource caravans') (Hobfoll, 2011), to successfully deal with demands. Indeed, a positive effect was observed between job and personal resources. This agrees with Slöetjes (2012) who found a significant relationship between job resources and personal resources. The mediating effect (in serial) was also statistically significant, lending support to the possibility that job resources activate personal resources that eventually influence work engagement. However, as previously theorised, individuals may place different motivational values on the resources they use to enhance their levels of engagement.

\section{Practical implications}

The findings of the study show that job demands (intrusion of work into private life) negatively influence iron-ore mineworkers' work engagement. Despite the job demands, mineworkers' work engagement can be increased by investing in interventions and a work environment that enhances job and personal resources. The present study 
suggests two potential interventions: firstly, increasing individual mindfulness awareness and PsyCap through training and development interventions, and secondly, designing work environments and organisational practices and/or policies that reflect respect and care for employees and allow supervisors to support their employees.

\section{Limitations and recommendations}

The present study explored the influence of only two personal resources, mindfulness and PsyCap, as mediators in the relationship between the job demands and mineworkers' levels of work engagement. Future studies may incorporate other personal resources and investigate their accumulative influence on mineworkers' work engagement (Schaufeli \& Taris, 2014; Slöetjes, 2012). The present study applied a quantitative methodology. As the work environment of mineworkers is unique, future researchers are encouraged to use qualitative methods to improve the understanding of the mining working environment, as well as the personal, work and home resources mineworkers employ to feel engaged in their daily work activities.

\section{Conclusion}

The purpose of this research was to investigate the mediating effect of both job and personal resources in the relationship between job demands and work engagement of mineworkers at two iron-ore mines in a remote area in South Africa. The results indicate that job and personal resources partially mediate (in parallel and in serial) this relationship. In light of these results, mining companies may need to consider what can be done to enhance the job and personal resources of their employees to help them cope with the challenges in mining workplace environments.

\section{Acknowledgements Competing interests}

The authors declare that they have no financial or personal relationships that may have inappropriately influenced them in writing this article.

\section{Authors' contributions}

M.K. was responsible for conceptualisation, literature review, data gathering, discussion of results, conclusion, limitations and practical implications. P.N. was responsible for research design, statistical analysis, presentation and discussion of results, conclusion and limitations.

\section{Funding information}

This research received no specific grant from any funding agency in the public, commercial or not-for-profit sectors.

\section{Data availability statement}

Data sharing is not applicable to this article as no new data were created or analysed in this study.

\section{Disclaimer}

The views and opinions expressed in this article are those of the authors and do not necessarily reflect the official policy or position of any affiliated agency of the authors.

\section{References}

Abrahamsson, L., Segerstedt, E., Nygren, M., Johansson, J., Johansson, B., Edman, I., et al. (2014). Gender, diversity and work conditions in mining, mining and sustainable development. Luleå: Luleå University of Technology Press.

Avey, J. B., Wernsing, T. S., \& Luthans, F. (2008). Can positive employees help positive organizational change? Impact of psychological capital and emotions on relevant
attitudes and behaviors. Journal of Applied Behavioral Science, 44(1), 48-70. attitudes and behaviors. Journal of Applied
https://doi.org/10.1177/0021886307311470

Bakker, A. B. (2009). Building engagement in the workplace. In R. J. Burke \& C. L. Cooper (Eds.), The peak performing organization, (pp. 50-72). Oxon: Routledge. https://doi.org/10.4324/9780203971611.ch3

Bakker, A. B., Tims, M., \& Derks, D. (2012). Proactive personality and job performance: The role of job crafting and work engagement. Human Relations, 65(10), 1359-1378. https://doi.org/10.1177/0018726712453471

Bakker, A. B., \& Demerouti, E. (2008). Towards a model of work engagement. Career Development International, 13(3), 209-223. https://doi.org/10.1108/136204308 10870476

Bakker, A. B., \& Demerouti, E. (2016). Job demands-resources theory: Taking stock and looking forward. Journal of Occupational Health Psychology, 22(3), 273-285.

Bakker, A. B., Demerouti, E., \& Verbeke, W. (2004). Using the job demands-resources model to predict burnout and performance. Human Resource Management 43(1), 83-104.

Bakker, A. B, Demerouti, E., \& Xanthopoulou, D. (2012). Why do engaged employees stay engaged? Ciencia \& Trabajo, 14 (special issue), 16-22.

Bakker, A. B., Hakanen, J., Demerouti, E., \& Xanthopoulou, D. (2007). Job resources boost work engagement, particularly when job demands are high. Journal of Educational Psychology, 99(2), 274-284. https://doi.org/10.1037/0022-0663. 99.2.274

Breevaart, K., \& Bakker, A. B. (2018). Daily job demands and employee work engagement: The role of daily transformational leadership behavior. Journa of Occupational Health Psychology, 23(3), 338-349. https://doi.org/10.1037/ ocp0000082

Brouze, K. L. (2013). Examining the mediating and moderating role of psychological capital in the job demands-resources model. Unpublished master's dissertation. University of Cape Town, South Africa.

Brown, K. W., \& Ryan, R. M. (2003). The benefits of being present: Mindfulness and its role in psychological well-being. Journal of Personality and Social Psychology, 84(4), 822-848. https://doi.org/10.1037/0022-3514.84.4.822

Chen, H., Chen, F., Zhu, D., Qi, H., \& Long, R. (2015). Burnout in Chinese coal mine safety supervision. Energy Policy, 85(C), 22-31.

Chimamise, C., Gombe, N. T., Tshimanga, M., Chadambuka, A., Shambira, G., \& Chimusoro, A. (2013). Factors associated with severe occupational injuries at a mining company in Zimbabwe, 2010: A cross-sectional study. Pan African Medical Journal, 14, 5. https://doi.org/10.11604/pamj.2013.14.5.1148

Constantini, A., De Paola, F., Ceschi, A., Sartori, U., Meneghini, A. M., \& Fabio, A. D. (2017). Work engagement and psychological capital in the Italian public administration: A new resource-based intervention programme. SA Journal of Industrial Psychology, 43(1), a1413. https://doi.org/10.4102/sajip.v4310.1413

Dane, E. (2011). Paying attention to mindfulness and its effects on task performance in the workplace. Journal of Management, 37(4), 997-1018. https://doi. org/10.1177/0149206310367948

Dane, E., \& Brummel, B. (2013). Examining workplace mindfulness and its relations to job performance and turnover intention. Human Relations, 67(1), 105-128. https://doi.org/10.1177/0018726713487753

De Beer, L. T., Tims, M., \& Bakker, A. B. (2016). Job crafting and its impact on work engagement and job satisfaction mining and manufacturing. South African Journa of Economic and Management Sciences, 19(3), 400-412. https://doi.org/10.4102/ sajems.v19i3.1481

De Bruin, G. P., \& Henn, C. M. (2013). Dimensionality of the 9-item Utrecht work engagement scale (UWES-9). Psychological Reports: Human Resources and Marketing, 112(3), 788-799. https://doi.org/10.2466/01.03.PR0.112.3.788-799

Demerouti, E., \& Bakker, A. B. (2011). The job demands-resources model: Challenges for future research. SA Journal of Industrial Psychology, 37(2), Art. \#974, 9. https://doi.org/10.4102/sajip.v37i2.974

Demerouti, E., Bakker, A. B., Nachreiner, F., \& Schaufeli, W. B. (2001). The job demandsresources model of burnout. Journal of Applied Psychology, 86(3), 499-512. https://doi.org/10.1037/0021-9010.86.3.499

Depenbrock, F. (2014). Being mindfully aware and engaged at work? The role of affect regulative processes for the relationship between daily levels of mindfulness and work engagement. Unpublished master's thesis. Maastricht University, The Netherlands.

Duong, D., Tuckey, M. R., Hayward, R. M., \& Boyd, C. M. (2015). Work-family conflict: The importance of differentiating between different facets of job characteristics. Work and Stress, 29(3), 230-245. https://doi.org/10.1080/02678373.2015. 1074629 
Emerson, R. M. (1976). Social exchange theory. Annual Review of Sociology, 2, 335-362.

Fernandez, C. P. (2007). Employee engagement. Journal of Public Health Managemen and Practice, 13(5), 524-552. https://doi.org/10.1097/01.PHH.0000285207. 63835.50

Field, A. (2005). Discovering statistics using SPSS (2nd edn.). Thousand Oaks, CA: SAGE.

Glazer, S. (2006). Social support across cultures. International Journal of Intercultural Relations, 30(5), 605-622. https://doi.org/10.1016/j.ijintrel.2005.01.013

Grobler, A., \& Joubert, Y. T. (2018). Psychological capital: Convergent and discriminant validity of a reconfigured measure. South African Journal of Economic and

Grover, S. L., Teo, S. T., Pick, D., Roche, M., \& Newton, C. J. (2018). Psychological capital as a personal resource in the JD-R model. Personnel Review, 47(4), 968-984.

Hair, J. F., Black, B., Babin, B., Anderson, R. E., \& Tatham, R. L. (2006). Multivariate data analysis (6th edn.). Upper Saddle River, NJ: Prentice Hall.

Hammer, L. B., Kossek, N. L., Yragui, N. L., Bodner, T. E., \& Hanson, G. C. (2009) Development and validation of a multidimensional measure of family supportive supervisor behaviors. Journal of Management, 35(4), 837-856. https://doi.org/ $10.1177 / 0149206308328510$

Henseler, J., Ringle, C. M., \& Sinkovics, R. R. (2009). The use of partial least squares path modeling in international marketing. Advances in International Marketing 20, 277-319. https://doi.org/10.1108/S1474-7979(2009)0000020014

Herbert, M. (2011). An exploration of the relationships between psychological capital (hope, optimism, self-efficacy, resilience), occupational stress, burnout and employee engagement. Unpublished master's thesis. Stellenbosch University, South Africa.

Hobfoll, S. E. (2011). Conservation of resource caravans and engaged settings. Journa of Occupational and Organizational Psychology, 84(1), 116-122. https://doi. org/10.1111/j.2044-8325.2010.02016.x

Inoue, A., Kawakami, N., Tsutsumi, A., Shimazu, A., Miyaki, K., Takahashi, M., et al (2014). Association of job demands with work engagement of Japanese employees: Comparison of challenges with hindrances (J-HOPE). PLoS One, 9(3), e91583. https://doi.org/10.1371/journal.pone.0091583

Kanfer, R., Frese, M., \& Johnson, R. E. (2017). Motivation related to work: A century of progress. Journal of Applied Psychology, 102(3), 338-355. https://doi.org/10.1037/ apl0000133

Kotzé, M. (2018a). How job resources and personal resources influence work engagement and burnout. African Journal of Economic and Management Studies, 9(2), 148-164. https://doi.org/10.1108/AJEMS-05-2017-0096

Kotzé, M. (2018b). The influence of psychological capital, self-leadership, and mindfulness on work engagement. South African Journal of Psychology, 48(2), 279-292. https://doi.org/10.1177/0081246317705812

Kotzé, M., \& Nel, P. (2018). The work-related psychological well-being of a mineworker In L. Marais, P. Burger \& D. Van Rooyen (Eds.), Mining and community in South Africa: From small town to iron town (pp. 199-214). New York: Routledge.

Langer, E. J., \& Moldoveanu, M. (2000). The construct of mindfulness. Journal of Socia Issues, 56(1), 1-9. https://doi.org/10.1111/0022-4537.00148

Leroy, H., Anseel, F., Dimitrova, N., \& Sels, L. (2013). Mindfulness, authentic functioning, and work engagement: A growth modelling approach. Journal of Vocational Behavior, 82(3), 238-247.

Liao, P-Y. (2011). Linking work-family conflict to job attitudes: The mediating role of social exchange relationships. The International Journal of Human Resource Management, 22(14), 2965-2980.

Luthans, F., \& Youssef-Morgan, C. M. (2017). Psychological Capital: An evidence-based positive approach. Annual Review of Organisational Psychology and Organizationa Behavior, 4, 339-366. https://doi.org/10.1146/annurev-orgpsych-032516-113324

Luthans, F., Avolio, B. J., Avey, J. B., \& Norman, S. M. (2007). Positive psychological capital: Measurement and relationship with performance and satisfaction. Leadership Institute Faculty Publications, Paper 11. Retrieved from http:// digitalcommons.unl.edu/leadershipfacpub/11

Luthans, F., Youssef, C., \& Avolio, B. (2007). Psychological capital: Developing the human competitive edge. Oxford: Oxford University Press.

Luthans, F., Youssef-Morgan, C., \& Avolio, B. (2015). Psychological capital and beyond New York: Oxford University Press.

Malinowski, P., \& Lim, H. J. (2015). Mindfulness at work: Positive affect, hope, and optimism mediate the relationship between dispositional mindfulness, work engagement and well-being. Mindfulness, 6(6), 1250-1262.

Marais, L., \& Cloete, J. (2013). Labour migration, settlement and mine closure in South Africa. Geography, 98(2), 77-84.

Marais, L., Burger, P., Van Rooyen, D., Lenka, M., Cloete, J., Denoon-Stevens, S., et al. (2018). The background to the Postmasburg study. In L. Marais, P. Burger \& D. Van Rooyen (Eds.), Mining and community in South Africa: From small town to iron town (pp. 5-22). New York: Routledge.

Markos, S., \& Sridevi, M. S. (2010). Employee engagement: The key to improving performance. International Journal of Business and Management, 5(12), 89-96. https://doi.org/10.5539/ijbm.v5n12p89

Maslach, C. (1993). Burnout: A multidimensional perspective. In W. B. Schaufeli, C. Maslach \& T. Marek (Eds.), Professional burnout: Recent developments in theory and research. Washington, DC: Taylor \& Francis.

Malherbe, S. A., \& Segal, N. (2000). A perspective on the South African Mining industry in the 21st Century: An independent report prepared for the Chamber of Mines of South Africa. Graduate School of Business and Genesis Analytics, University of Cape Town. Retrieved from http://pmg-assets.s3-website-eu-west-1.amazonaws. com/docs/segal.pdf.
Mauno, S., Kinnunen, U., \& Ruokolainen, M. (2007). Job demands and resources as antecedents of work engagement: A longitudinal study. Journal of Organizational Behavior, 70(1), 149-171. https://doi.org/10.1016/j.jvb.2006.09.002

Muse, L. A., \& Pichler, S. (2011). A comparison of types of support for lower-skill workers: Evidence for the importance of family supportive supervisors. Journal of Vocational Behavior, 79(3), 653-666. https://doi.org/10.1016/j.jvb.2011.04.005

Mphahlele, P., Els, C., De Beer, L. T., \& Mostert, K. (2018). Investigating strengths and deficits to increase work engagement: A longitudinal study in the mining industry. SA Journal of Human Resource Management/SA Tydskrif vir Menslikehulpbronbestuur, 16(0), a900. https://doi.org/10.4102/sajhrm.v16i0.900

Palo, J., \& Rothmann, S. (2016). Work engagement in the mining industry in South Africa: The role of tasks and relationships. Journal of Psychology in Africa, 26(3), 221-229. https://doi.org/10.1080/14330237.2016.1185901

Parker, G. B., \& Hyett, M. P. (2011). Measurement of well-being in the workplace: The development of the work well-being questionnaire. Journal of Nervous and Mental Disease, 199(6), 394-397. https://doi.org/10.1097/NMD.0b013e31821cd3b9

Paul, P. S., \& Maiti, J. (2007). The role of behavioral factors on safety management in underground mines. Safety Science, 45(4), 499-471. https://doi.org/10.1016/ j.ssci.2006.07.006

Petchsawang, P., \& McLean, G. N. (2017). Workplace spirituality, mindfulness, meditation, and work engagement. Journal of Management, Spirituality \& Religion 14(3), 216-244. https://doi.org/10.1080//14766086.2017.1291360

Phakathi, T. S. (2011). Worker responses to work reorganisation in deep-level gold mining workplace: Perspectives from the rock-face. DPhil thesis. Oxford University, England.

Rhoades, L., \& Eisenberger, R. (2002). Perceived organizational support: A review of the literature. Journal of Applied Psychology, 87(4), 698-714. http://doi.org/ 10.1037/0021-9010.87.4.698

Ringle, C. M., Wende, S., \& Becker, J. M. (2015). SmartPLS 3. Boenningstedt: SmartPLS $\mathrm{GmbH}$. Retrieved from http://www.smartpls.com.

Rothmann, S., \& Joubert, J. H. M. (2007). Job demands, job resources, burnout and work engagement of managers at a platinum mine in the North West Province. SA Journal of Business Management, 38(3), 49-61.

Roux, S. (2010). The relationship between authentic leadership, optimism, self-efficacy and work engagement: An exploratory study. Unpublished master's thesis. Stellenbosch: Stellenbosch University.

Sameer, Y. M. (2018). Innovative behaviour and psychological capital: Does positivity make any difference? Journal of Economics and Management, 32(2), 76-101

Schaufeli, W. B. (2013). What is engagement? In C. Truss, K. Alfes, R. Delbridge, A. Shantz \& E. Soane (Eds.), Employee engagement in theory and practice (pp. 2657-2669). London: Routledge.

Schaufeli, W. B., \& Bakker, A. B. (2004). Job demands, job resources and their relationship with burnout and engagement: A multi-sample study. Journal of Organizational Behavior, 25(3), 293-315. https://doi.org/10.1002/job.248

Schaufeli, W. B., Bakker, A. B., \& Salanova, M. (2006). The measurement of work engagement with a brief questionnaire: A cross-national study. Educational and Psychological Measurement, 66(4), 701-716. https://doi.org/10.1177/001316440 5282471

Schaufeli, W. B., Bakker, A. B., \& Van Rhenen, W. (2009). How changes in job demands and resources predict burnout, work engagement, and sickness absenteeism. Journal of Organizational Behavior, 30(7), 893-917. https://doi.org/10.1002/ journal 595

Schaufeli, W., \& Salanova, M. (2007). Work engagement: An emerging psychological concept and its implications for organizations. In S. W. Gilliland, D. D. Steiner \& D. P. Skarlicki (Eds.), Research in social issues in management (Volume 5): Managing social and ethical issues in organizations (pp. 135-177). Greenwich, CT: Information social and ethica

Schaufeli, W., Salanova, M., Gonzalez-Roma, V. \& Bakker, A. (2002). The measurement of engagement and burnout: A two sample confirmatory factor analytic approach Journal of Happiness Studies, 3(1), 71-92. https://doi.org/10.1023/A:1015630 930326

Schaufeli, W. B. \& Taris, T. W. (2014). A critical review of the job demands-resources model: Implications for improving work and health. In G. Bauer \& O. Hämmis (Eds.), Bridging occupational, organizational and public health (pp. 43-68). Dordrecht: Springer.

Schaufeli, W. B., Martinez, I. M., Pinto, A. M., Salanova, M., \& Bakker, A. B. (2002) Burnout and engagement in university students: A cross-national study. Journal of Cross-Cultural Psychology, 33(5), 464-481. https://doi.org/10.1177/002202210 2033005003

Simons, J. C., \& Buitendach, J. H. (2013). Psychological capital, work engagement and organisational commitment amongst call centre employees in South Africa. SA Journal of Industrial Psychology, 39(2), Art. \#1071, 12 pages. https://doi.org/ 10.4102/sajip.v39i2.1071

Slöetjes, T. (2012). Personal resources in the Job Demands-Resources model: The influence of proactive behavior, assertiveness, and worker flexibility. Unpublished master's thesis. Utrecht University, The Netherlands.

Snyder, C. R., Harris, C., Anderson, J. R., Holleran, S. A., Irving, L. M., Sigmon, S. T., et al (1991). The will and the ways: Development and validation of an individualdifferences measure of hope. Journal of Personality and Social Psychology, 60(4), 570-585.

Sonnentag, S. (2017). A task-level perspective on work engagement: A new approach that helps to differentiate the concepts of engagement and burnout. Burnout Research, 5, 2-20. https://doi.org/10.1016/j.burn.2017.04.001 
Taris, T. W., Ybema, J. F., \& Van Beek, I. (2017). Burnout and engagement: Identical twins or just close relatives? Burnout Research, 5, 3-11. https://doi.org/10.1016/ j.burn.2017.05.002

Ten Brummelhuis, L. L., \& Bakker, A. B. (2012). A resource perspective on work-home interface: The work-home resource model. American Psychologist, 67(7), 545-556. https://doi.org/10.1037/a0027974

Van Der Broeck, A., De Cuyper, J., De Witte, H., \& Vansteenkiste, M. (2010). Not all job demands are equal: Differentiating job hindrances and job challenges in the job demands-resources model. European Journal of Work and Organizational Psychology, 19(6), 735-759.

Wang, X, Liu, L., Zou, F., Junhui, H., \& Wu, H. (2017). Associations of occupational stressors, perceived organisational support, and psychological capital with work engagement among Chinese female nurses. BioMed Research International, 2017(2), 1-11. Article ID 5284628. https://doi.org/10.1155/2017/5284628
Xanthopoulou, D., Baker, A. B., Heuven, E., Demerouti, E., \& Schaufeli, W. B. (2008). Working in the sky: A diary study on work engagement among flight attendants. Journal of Occupational Health Psychology, 13(4), 345-356. https://doi.org/ 10.1037/1076-8998.13.4.345

Youssef, C. M., \& Luthans, F. (2007). Positive organisational behaviour in the workplace: The impact of hope, optimism and resilience. Journal of Management, 33(5), 774-800. https://doi.org/10.1177/0149206307305562

Zhai, Q., Wang, S., \& Weadon, H. (2017). Thriving at work as a mediator of the relationship between workplace support and life satisfaction. Journal of Management and Organization, 1-17. https://doi.org/10.1017/jmo.2017.62

Zheng, C. S., Gunasekare, A., \& Blaich, S. (2018). Mindfulness and work engagement: The mediating effect of psychological flourishing. Academy of Management Annual Meeting Proceedings, 2018(1), 12210. https://doi.org/10.5465/AMBPP.2018. 12210abstract 